\title{
ANALISIS UPACARA "PUKUL SAPU" dI NEGERI MORELLA KECAMATAN LEIHITU KABUPATEN MALUKU TENGAH
}

\author{
Abdul Manaf Tubaka \\ Dosen Jurusan Sosiologi Agama IAIN Ambon \\ *) e-Mail: amtubaka@gmail.com
}

\begin{abstract}
ABSTRAK
This study aims to reveal the meaning of the tradition of Pukul Sapu ceremony in Morella which is held annually on the 7th of syawal or seven days after Eid al-Fitr. The method used in this study is the verstehen method with a qualitative approach. Research instrument is the researcher itself with interview method, participatory observation to understand the context of an event. The results of the study illustrate that the tradition of Pukul Sapu in Morella with the symbol attributes used has a variety of meanings for the people of Morella. Therefore, these traditions can drive people's behavior in their daily life. In addition, Pukul Sapu tradition becomes a construction of a unique cultural identity and gives influence to the social integration of the Morella people. The existence of Pukul Sapu Ceremony becomes a marker of historical awareness for people of Morella and has functional value for people of Maluku in general.
\end{abstract}

Keywords: Tradition, Pukul Sapu, and Symbol Meaning.

\section{PENDAHULUAN}

Budaya adalah sistem yang mempunyai koherensi. Bentuk-bentuk simbolis yang berupa kata, benda, laku, mite, sastra, lukisan, nyanyian, musik, kepercayaan mempunyai kaitan erat dengan konsep-konsep epistemologis dari system pengetahuan masyarakatnya. ${ }^{1}$ Untuk itu, bentuk ekspresi manusia tidak bisa dilihat hanya sekedar kegiatan tanpa makna. Keseluruhan aktivitas manusia tentu dilandasi oleh dasar epistemologis yang memungkinkan suatu kebudayaan dapat berfungsi. Keberlangsungan suatu budaya dalam kategori-kategori sejarah dan simbolisnya yang dijelaskan oleh Huaco adalah dasar bagi penjelasan struktur dan fungsi kebudayaan secara komprehensif. Ekspresi kebudayaan dengan demikian bukan sesuatu yang tanpa makna. Suatu kebudayaan memiliki struktur dasar yang

${ }^{1}$ Kuntowijoyo. 2006. Budaya dan Masyarakat. Yogyakarta: Tiara Wacana. h. xi. memberikan model bagi implementasinya dalam kehidupan sosial. Meminjam kategori budaya dari Williams (1981), bahwa dalam budaya kita menemukan adanya tiga komponen pokok, yaitu lembaga-lembaga budaya, isi budaya, dan efek budaya atau norma-norma. Dengan kata lain, lembaga budaya menanyakan siapa menghasilkan produk budaya, siapa mengontrol, dan bagaimana control itu dilakukan; isi budaya menanyakan apa yang dihasilkan atau symbol-simbol apa yang diusahakan; efek budaya menanyakan konsekuensi apa yang diharapkan dari proses budaya itu. $^{2}$

Dari penjelasan ini kita dapan melihat bagaimana suatu proses simbolis dari suatu kebudayaan memiliki arti yang menggerakan masyarakat. Betapa besar makna dari symbol kebudayaan ditunjukan dengan keterlibatan orang-orang dalam memproduksi, merawat dan memberikan efek nilai bagi berbagai macam

\footnotetext{
${ }^{2}$ Ibid. h. 8.
} 
kepentingan hidup suatu masyarakat. Untuk itu, kita dapat melihat bagaimana, praktek budaya suatu masyarakat di pelihara atau diawetkan melalaui serangkaian proses belajar dari generasi ke generasi berikutnya dan menjadi pola anutan bagi keberlangsungan hidup masyarakat. Berger menyebut pola pewarisan budaya ini diperoleh melalui tiga proses yaitu eksternalisasi, objektivasi, dan Internalisasi. Eksternalisasi merupakan tahap awal dimana setiap individu menanyakan tentang apa yang merela lihat dan mereka harapkan. Dari tahap keinginan ini kemudian diwujudkan dalam persetujuan bersama yang disebut objektivasi. Nilai-nilai yang telah terobjektivasi ini kemudian diinternalisasi oleh setiap anggota masyarakat menjadi milik yang harus dipertahankan. Pada tahap internalisasi inilah kemudian suatu symbol kebudayaan dipertahankan dan diekspresikan menjadi miliknya.

Simbol dan makna budaya kemudian menjadi pandangan hidup yang menggerakan masyarakat. Budaya yang telah terinternalisasi tidak datang begitu saja, tetapi mengalami proses sejarah dengan masyarakatnya dimana mereka memproduksi apa yang menjadi kehendak bersama. Simbol ikat kepala merah, sapu Lidi dari pohon Enau yang digunakan untuk memukul badan serta upacara "Pukul Sapu" itu sendiri adalah bagian dari model produksi budaya yang lahir dari kehendak masyarakat untuk memberikan makna atas proses sejarah yang mereka lakukan. Upacara "Pukul Sapu" memberikan makna bagi suatu proses sosial yang terjadi dimasa lampau dan dikenang terus menerus memberikan penekanan betapa kesadaran sejarah atas peristiwa budaya begitu penting utuk memberikan semangat dan spirit serta kekuatan dalam menatap kehidupan yang lebih baik. Pada aras suprastruktur inilah, sumber sosial masyarakat yang berkaitan dengan ekonomi, geografi, pendidikan dan lain-lain mendapati bentuknya dalam model organisasi sosial.

Sebagai kajian budaya, hal penting yang harus diperjelas dalam studi ini adalah bagaimana menjelaskan kebudayaan dalam konteks studi ini karena ini merupakan kajian kebudayaan masyarakat. Dalam konteks ini, definisi kebudayaan mengacu pada Geertz, namun bukan berarti menolak definisi-definisi kebudayaan yang diajukan oleh para ahli yang lain. Kebudayaan menurut Geertz (1973) adalah pola dari pengertian-pengertian atau makna-makna yang terjalin secara menyeluruh dalam simbolsimbol dan ditransmisikan secara historis, juga merupakan system mengenai konsepsi-konsepsi yang diwariskan dalam bentuk simbolik, yang dengan cara itu manusia dapat berkomunikasi, melestarikan, dan mengembangkan pengetahuan dan sikapnya terhadap kehidupan. ${ }^{3}$

Sejalan dengan itu, Baal menjelaskan salah satu manifestasi dari pengetahuan manusia tentang dunianya ada dalam aktivitas yang berhubungan dengan religi, karena religi merupakan sistem-simbol sebagai media bagi manusia untuk berkomunikasi dengan dunianya. ${ }^{4}$ Selain itu, system religi dan upacara keagamaan merupakan unsur kebudayaan universal yang paling sukar berubah dan paling sukar dipengaruhi oleh kebudayaan lain. ${ }^{5}$ Gagasan atau kepercayaan yang terekspresikan dalam berbagai

3 Irwan Abdullah. 2002. Simbol Makna dan Pandangan Hidup Jawa: Analisis Gunungan pada Upacara Garebek. Yogyakarta: Balai Kajian Sejarah dan Nilai Tradisional. h. 1.

${ }^{4}$ Baal, J. Van. 1971. Symbols for Communication: an Introduction to the Anthropological Study of religion ( Sudies of Developing Countries 11). Asen: Van Gorrcum. h. 242 .

${ }^{5}$ Koentjaraningrat. 1980. Kebudayaan, Mentalitet dan Pembangunan. Jakarta: Gramedia. h. 12-13. 
upacara, baik itu upacara ritual maupun seremoni adalah rangkain prosesi yang bernilai khidmat bagi suatu masyarakat dan ini yang bisanya sulit untuk berubah atau terpengaruh oleh kebudayaan lain. Dengan demikian, kajian mengenai upacara yang dilakukan oleh berbagai suku bangsa menjadi menarik untuk melacak gagasan-gagasan yang melarbelakangi tindakan tersebut.

Kajian kebudayaan ini menarik karena biasanya dalam upacara manusia mengekspresikan apa yang menjadi kehendak dalam pikiran mereka. Dengan kata lain, mempelajari suatu upacara berarti kita mempelajari nilai-nilai yang sangat penting dalam masyarakat. Selain itu, dalam upacara kita menemukan nilai-nilai masyarakat yang sukar kita amati dalam kehidupan yang biasa. Turner menjelaskan bahwa dalam upacara kita dapat menemukan, "to understanding of how people think and feel about those relationship, and about the natural and social environments in which they operate". 6

Upacara selalu mengingatkan manusia tentang eksistensi mereka dan hubungan mereka dengan lingkungan karena melalui upacara warga suatu masyarakat dibiasakan untuk menggunakan simbol-simbol yang bersifat abstrak yang berbeda pada tingkat pemikiran untuk berbagai kegiatan sosial yang ada di dalam kehidupan mereka sehari-hari. ${ }^{7} \quad$ Upacara selalu disertai dengan simbol agar masyarakat bisa membedakan, memahami, dan mengenal suatu kebudayaan yang dimiliki. Demikian halnya dengan upacara "Puku Sapu" dalam kajian ini.

6 Voctor W. Turner. 1967. Symbols in ndembu ritual, in Victor Turner, The Forest of Symbols: Aspects of Ndembu Ritual. Ithaca: Crnell University Press. h. 6.

7 Irwan Abdullah. 2002. Simbol Makna dan Pandangan Hidup Jawa: Analisis Gunungan pada Upacara Garebek. Yogyakarta: Balai Kajian Sejarah dan Nilai Tradisional. h. 3.
Kajian ini tidak hanya membahas upacara Pukul Sapu, tetapi juga simbol-simbol ikat kain merah dan sapu lidi dalam upacara Pukul Sapu oleh negeri Hausihu Morella. Upacara Puku Sapu merupakan upacara masyarakat Morella yang biasa disaksikan pada setiap $\mathrm{H}+7$ lebaran Idul Fitri. Seperti upacara pada masyarakat lainnya, upacara Pukul Sapu ini menjadi menarik dan sangat unik serta tata cara pelaksanaannya yang rumit. Sangat unik dan menarik sebab upacara ini dilaksanakan pada setiap tujuh hari setelah lebaran dan karena itu, orang-orang dari berbagai daerah baik dalam maupun luar negeri datang ke upacara Pukul Sapu . Upacara Pukul Sapu juga unik sebab yang ikut bukan saja orang dalam negeri Morella, tetapi orang luar bahkan orang "bule" juga diperbolehkan setelah mengikuti rangkaian acara yang dibuat oleh tua-tua adat negeri Morella.

Unsur-unsur yang terdapat dalam upacara Pukul Sapu adalah simbolisasi makna kehidupan suatu masayarakat. Untuk itu, unsur paling penting dalam upacara Pukul Sapu adalah ekspresi rasa syukur atas suatu kemenangan. Pukul Sapu sendiri dinami demikian, sebab upacara itu menonjolkan simbol Sapu Lidi yang digunakan untuk memukul badan hingga berdarah-darah. Analisis symbol di sini dapat membantu menjelaskan secara benar nilai-nilai yang ada dalam masyarakat dan menghilangkan keraguan kita tentang spekulasi penjelasan suatu kebenaran.

\section{MASALAH PENELITIAN}

Upacara Pukul Sapu ini sudah cukup tua usianya, sejak penjajah Belanda meninggalkan Maluku yakni sekitar 366 tahun.Hal ini terjadi ketika Belanda menahan kapitan Telukabessy pada 27 oktober 1646 M. Tradisi berperang akibat kolonisasi yang cukup lama membuat 
kosmologi masyarakat penuh dengan alam kekuatan dan keberanian. Namun, kehadiran upacara Pukul Sapu telah disesuaikan dengan nilai-nilai Islam sebab pada waktu itu masyarakat Morella sudah memeluk agama Islam. Karena itu, upacara Pukul sapu ini tidak tampak sebagai upacara Islam, tetapi merupakan kombinasi dari nilai-nilai Islan dan adat yang kemudian dikemas dalam tata cara pelaksanaanya. Untuk itu, doadoa yang dil akukan mengakomudasi tradisi Islam dan adat.

Dalam kajian Turner (1967;1969;1981) mengenai symbol-simbol yang dikaji di Ndembu ternyata bahwa symbol-simbol yang ada tidak hanya memiliki satu arti, tetapi bisa beberapa arti yang disebut multivocal atau Polysemy. Ditunjukan oleh Turner bahwa suatu warna merupakan simbol dari beberapa konsep. ${ }^{8}$ Simbol dari beberapa konsep itu dapat ditunjukan pada warna putih yang artinya adalah symbol dari kesuburan, kemurnian, kesehatan, dan nasib baik. Atau warna merah sebagai symbol darah, keberanian, dan bahaya. Dengan demikian, dapatlah diduga bahwa simbol-simbol yang dimiliki masyarakat juga memiliki arti yang multivocal tentu hal ini membutuhkan kajian secara khusus.

Dari uraian diatas dan gambaran sementara yang saya miliki tentang upacara Pukul Sapu di negeri Morella, dapat saya mengajukan beberapa pertanyaan penelitian yang akan dibahas dalam kajian ini:

1. Apakah simbol-simbol dalam upacara Pukul Sapu memiliki lebih dari satu arti (multivocal) ?

2. Bagaimana pandangan orang Morella tentang dirinya dalam kehidupan dan apa

${ }^{8}$ Ibid. 20 kaitannya dengan symbol pukul badan sampai berdarah-darah?

3. Mengapa upacara ini masih bertahan dan memiliki arti penting bagi masayarakat Morella?

\section{KERANGKA TEORI}

Studi tentang kebudayaan tidak selalu berjalan dalam koridor generiknya, sebab aspek kesejarahan dari kebudayaan merupakan bahan diskusi yang belum selesai. Hal ini dapat dilihat dari penjelasan Irwan Abdullah mengenai mencairnya batas-batas kebudayaan. Gugatan yang sama juga dilontarkan oleh Asad terhadap definisi yang lebih berorienstasi generik. ${ }^{9}$ Aspek yang dianggap Talal Asad masalah dalam definisi Geertz tentang kebudayaan, karena ia dianggap Asad sebagai yang tidak merespon perubahan-perubahan struktur sosial yang menjadi ruang terbentuknya kebudayaan.

Kebudayaan yang termanifestasi dalam seluruh kedirian manusia mulai dari sistem gagasan atau pemikiran sampai kepada hal-hal yang diciptakan secara material selalu berinteraksi dalam ruang dan waktu. Pola negosiasi kebudayaan dalam ruang dan waktu inilah yang kemudian membuat pendefinisian tidak selalu mengeikuti generiknya. Namun apapun perdebatannya, kebudayaan selalu menjadi pola anutan hidup yang tercermin dari perawatan tradisi dari berbagai suku bangsa.

Tradisi upacara Pukul Sapu di negeri Morella sudah berlangsung lama dan selalu dilaksakan setiap hari ketujuh setelah hari raya Idut Fitri. Penempatan hari ke tujuh setelah lebaran Idul Fitri bukan sesuatu yang kebetulan. Pemilihan waktu merupakan suatu gagasan yang

9 Abdullah, Irwan. 2006. Konstruksi dan Reproduksi Kebudayaan. Yogyakarta: Pustaka Pelajar. h. 19. 
dipikirkan oleh masyarakat Morella sebagai simbol yang berrelasi dengan kehidupan mereka yang kemudian dimanifestasikan dalam upacara Pukul Sapu tersebut. Upacara ini telah berlangsung dari beberapa generasi yang memperlihatkan betapa upacara ini sangat penting bagi masyarakat Morella.

Konsep Pukul Sapu perlu dijelaskan untuk tidak menimbulkan kesalapahaman. Konsep ini merupakan suatu penamaan terhadap prosesi upacara yang unsur utamanya adalah Sapu Lidi yang digunakan untuk memukul badan sampai berdarah. Untuk itulah upacara ini dinamakan upacara Pukul Sapu. Upacara ini dihadiri oleh orang-orang berdesakan untuk menyaksikan bagaimana pemuda-pemuda negeri Morella saling memukul badan mereka dengan sapu lidi hingga berdarah-darah.

Konsep lain yang perlu dijelaskan adalah konsep upacara, agar tidak menyesatkan pembaca, karena dalam bahasa Inggris kita mengenal dua konsep yaitu ritual dan ceremony. Ritual itu sendiri dapat didefinisikan sebagai "Prescribed formal behavior for occasions not given over to technological routine, having reference to beliefe in mystical being or powers". ${ }^{10}$ Kepercayaan terhadap supernatural di sini sering dimanifestasikan lewat pemberian sesaji, berdoa, menyanyikan lagu-lagu sacral karena ritual ini bersifat lebih suci dan keramat. ${ }^{11}$

Selanjutnya ceremony yang berasal dari bahasa latin (caeremonia), diartikan oleh Charles Winick dalam Dictionary of Antrhopology sebagai, "A fixed or sanctioned pattern of

10 Voctor W. Turner. 1967. Symbols in ndembu ritual, in Victor Turner, The Forest of Symbols: Aspects of Ndembu Ritual. Ithaca: Crnell University Press. h. 19.

11 Irwan Abdullah. 2002. Simbol Makna dan Pandangan Hidup Jawa: Analisis Gunungan pada Upacara Garebek. Yogyakarta: Balai Kajian Sejarah dan Nilai Tradisional. h. 10. behavior which surrounds various phases of life, often serving religious or aesthetic ends and confirming the group's celebration of a particular situation." 12

Definisi ceremony ini menurut Abdullah ternyata sangat luas dari pada ritual karena di dalamnya meliputi sejumlah antar hubungan dan menghubungkan berbagai ritual. ${ }^{13}$ Upacara ini biasanya dihubungkan dengan peristiwa-peristiwa penting dalam masyarakat. Dengan melihat batasan ini, maka saya menggolongkan upacara Pukul Sapu sebagai upacara jenis yang kedua, yaitu ceremony karena upacara Pukul Sapu merupakan tingkah laku pengukuhan dari pernyataan kelompok terhadap situasi tertentu yang terjadi dimasa lampau, dan dihadirkan dalam setiap hari raya Idul Fitri sebagai hari kemenangan bagi umat Islam setelah sebulan menjalankan ibadah puasa yang di wajibkan oleh Allah SWT.

Konsep selanjutnya yang perlu saya jelaskan adalah konsep simbol yang merupakan konsep utama dalam kajian ini. Turner (1967:19) menyatakan bahwa symbol adalah: "...a thing regarded by general consent as naturally typifying or representing or recalling something by prossession of analogous qualities or by association in fact or thougt." Definisi ini menampakkan bahwa si pemiliknya "memadatkan" simbol-simbol kiasan atau gambaran tentang dunia nyata, baik dalam kenyataan maupun pada tingkat ide karena symbol-simbol religious merupakan petunjuk bagi perilaku manusia. Dengan kata lain, simbol

12 Charles Winik. 1977. Dictionary of Antropology. New Jersey: Littlefied, Adams \& Company. h. 105 .

13 Irwan Abdullah. 2002. Simbol Makna dan Pandangan Hidup Jawa: Analisis Gunungan pada Upacara Garebek. Yogyakarta: Balai Kajian Sejarah dan Nilai Tradisional. h. 10. 
dalam masyarakat Morella sebagai bagian dari masyarakat Maluku tidak lain merupakan petunjuk bagi perilaku orang Morella. Dengan demikian symbol merupakan alat bantu yang dapat menggerakan masyarakatnya. ${ }^{14}$

Pendekatan yang mau digunakan untuk menganalisis masalah symbol dalam upacara Pukul Sapu ini adalah pendekatan yang disebut Turner sebagai "prosesual simbologi", yaitu suatu kajian mengenai bagaimana symbol menggerakan tindakan sosial dan melalui proses yang bagaimana symbol memperoleh dan memberikan arti kepada masyarakat dan pribadi. ${ }^{15}$ Pendekatan ini akan memungkinkan kita untuk mengungkapkan arti-arti symbol dan selanjutnya mengetahui pikiran-pikiran atau ide-ide masyarakat, apalagi mengingat bahwa symbol merupakan pedoman bagi kelompok-kelompok, hubungan-hubungan, norma-norma, dan kepercayaan masyarakat.

\section{METODE PENELITIAN}

Penelitian ini menggunakan paradigama fenomenologi untuk menafsir data melalui "kaca mata" si pelaku atau yang lazim disebut "inside view". Untuk mendapatkan data sesuai dengan persoalan penelitian, maka pengumpulan data dibagi ke dalam dua bagian yaitu data primer dan data sekunder. Data primer dengan menentukan informan kunci. Data diperoleh dari pengamatan (observasi) di lapangan dan wawancara mendalam dengan tokoh-tokoh adat, tokoh pemuda kemudian menggali data mengenai realitas masyarakat Morella. Untuk membantu wawancara, disusun sejumlah pertanyaan sebagai pedoman wawancara, kemudian menggunakan

\footnotetext{
${ }^{14}$ Ibid. 12

${ }^{15}$ William Armand Lessa and Evon Z. Vogt (eds). 1979. Reader in Comparative Religion: an Anthropological Approach. New York: Harper \& Row Publishers. h. 91.
}

tape recorder untuk merekam setiap pembicaraan, disamping itu membuat catatan harian (self Monitory) dan pengambilan dokumentasi yang dianggap penting untuk mendukung hasil penelitian.

Mewawancarai tokoh yang ahli dalam sejarah Morella untuk mendapat penjelasan sehingga mempermudah melakukan interpretasi yang lebih dapat dipertanggungjawabkan. Tahap selanjutnya baru proses analisis dilakukan untuk menarik kesimpulan-kesimpulan mengenai pikiran-pikiran atau agagasan-gagasan mengenai upacara pikiran-pikiran dan gagasan-gagasan yang menjadi dasar tindakan mereka dalam upacara Pukul Sapu.

\section{MAKNA SIMBOL PUKUL SAPAU DAN KAIN BERANG MERAH}

Suatu tradisi merupakan pewarisan serangkaian kebiasaan dan nilai-nilai yang diwariskan dari suatu generasi kepada generasi berikutnya. Nilai-nilai yang diwariskan berupa nilai-nilai yang oleh masyarakat pendukungnya masih dianggap baik, serta relevan dengan kebutuhan kelompok. Dalam suatu tradisi selalu ada hubungannya dengan upacara tradisional. Oleh karena itu upacara tradisional merupakan warisan budaya leluhur yang dipandang sebagai usaha manusia untuk dapat berhubungan dengan arwah para leluhur. Pada umumnya mereka masih mempunyai anggapan bahwa roh para leluhur dianggap masih dapat memberikan keselamatan dan perlindungan kepada keluarga yang ditinggalkan. Agar tujuannya dapat tercapai maka mereka mengadakan pendekatan melalui berbagai bentuk upacara baik itu upacara ritual maupun upacara ceremonial. Dalam upacara ini dapat dipakai untuk mengukuhkan kembali nilai-nilai dan keyakinan yang berlaku dalam masyarakat. Oleh karena itu upacara merupakan salah satu 
kegiatan sosial yang sangat diperhatikan, dalam rangka menggali tradisi atau kebudayaan daerah dan pengembangan kebudayaan nasional.

Dengan demikian, dalam setiap kebudayaan terdapat norma-norma atau nilai-nilai yang menjadi pedoman bagi masing-masing warga masyarakat pendukungnya dalam bertingkah laku atau bergaul dengan sesamanya. Norma-norma atau nilai-nilai dapat dimengerti oleh warga masyarakat selaku pendukung kebudayaan tersebut melalui belajar, baik secara formal maupun non formal. Hal yang serupa juga diungkapkan oleh Peursen bahwa kebudayaan merupakan semacam sekolah di mana manusia belajar.

Menurut Peursen (1974), upacara tradisional lebih dari sebuah mitos di mana fungsinya tidak hanya sekedar memberikan hiburan tetapi yang penting upacara itu dapat mengukuhkan nilai-nilai tradisi tentang kebaikan, kehidupan, kesuburan, juga penyucian. Selain itu upacara berfungsi pula untuk mengukuhkan ikatan solidaritas. Dalam hubungan dengan masalah tersebut, pemangku pemerintahan Negeri Hausihu Morella mengatakan bahwa Atraksi adat Pukul Sapu Lidi ini bertujuan untuk menjalin silturrahim dengan sesame manusia, saling menjalin kebersaam dalam ruang budaya bersama.

Tradisi Pukul sapu sebagai bagian dari ekspresi kebudayaan memiliki makna yang mendalam bagi masyarakat penggunanya. Tradisi Pukul Sapu ini diadakan setiap 7 syawal setelah selesai melaksanakan lebaran Idul Fitri. Biasanya setiap selesai lebaran Idul Fitri, masyarakat Islam Hausihu Morella melaksanakan ibadah puasa syawal selama enam hari sebagaimana praktik yang dilakukan oleh nabi Muhammad SAW. Praktek ibadah puasa ini memang sudah menjadi aktivitas ibadah tambahan bagi masyarakat muslim.

Sebagaimana praktek budaya, upacara pukul sapu diadakan dengan seperangkat simbolsimbol yang tentu saja mengandung makna yang ada di dalamnya. Makna yang terkandung di dalam symbol-simbol yang digunakan pun tidak bersifat tunggal, tetapi boleh jadi bermakna banyak. Dalam kajian ini, akan dilihat, bagaimana simbol Sapu Lidi, Kain Berang berwrna Merah maupun warna Kuning yang dijadikan sebagai focus analisis ini. Di samping itu, pandangan hidup yang menggerakan masyarakat Morella dalam kaitannya dengan eksistensi Pukul Sapu ini menjadi bagian dari focus kajian dengan melihat bagaimana masyarakat Morella mempertahankan atraksi Upacara Pukul Sapu yang menurut pengetahuan masyarakat Morella, atraksi ini sudah ada sejak masyarakat Morella masih tinggal di negeri lama yaitu di benteng Kapahaha hingga sampai sekarang dikenal sebagai masyarakat Hausihu Morella.

Atraksi Pukul Sapu ini penulis sebut sebagai suatu Upacara Ceremoni dan bukan suatu Upacara ritual sebab upacara Ceremony tentu berbeda maknanya dengan suatu ritual. Walaupun dalam setiap upacara Ceremoni itu, ada unsurunsur yang diperuntukan bagi usaha untuk memohon doa kepada Tuhan sebagaimana tujuan yang ingin dicapai dalam upacara tersebut. Seperti doa-doa yang dipanjatkan. Untuk itu, Upacara Pukul Sapu ini, merupakan suatu tradisi yang dilakukan untuk mengenang suatu peristiwa bersejarah. Peristiwa bersejarah ini berkaitan dengan eksistensi masyarakat Morella itu sendiri sehingga menjadi penting untuk dikenang oleh masyarakat tersebut.

Atraksi Pukul Sapu oleh masyarakat penggunanya merupakan suatu pewarisan nilai- 
nilai yang hidup di tengah masyarakat. Eksistensi Pukul Sapu menjadi semacam nilai dan norma yang menggerakan masyarakat untuk terus menunjukan eksistensi dirinya di tengah realitas sosial. Hal ini boleh dikatakan sebagai bagian dari politik identitas yang diekspresikan untuk mengenang suatu peristiwa perang Kapahaha yang berhubungan dengan proses historisitas masyarakat Morella dalam melawan bangsa Belanda. Memoritas koletif ini dirawat secara generative untuk menggambarkan bagaimana masyarakat Hausihu Morella dengan gigih mempertahankan harkat dan martabatnya sebagai suatu entitas primordial yang perlu diwaspadai. Hal ini menjadi sesuatu yang lumrah bahkan wajib bagi setiap suku bangsa manapun untuk bangkit melawan penjajahan.

Atraksi Pukul Sapu ini menjadi menarik dan memiliki makna yang mendalam, ketika dikaitkan dengan nilai-nilai agama yang memberikan semangat bagi suatu masyarakat untuk mewartakan semangat patriot (kabaresi) untuk melawan penjajahan. Bukan saja nilai-nilai agama yang menggerakan masyarakat, tetapi nilai-nilai budaya yang dikonstruksi oleh masyarakat untuk menjaga kelangsungan hidup mereka. Atraksi Pukul Sapu sebagai suatu ekspresi kebudayaan sudah dikenal sejak masyarakat Morella masih berada dalam suatu komunitas kecil di benteng Kapahaha sekitar tahun 1646. Hal ini semacam suatu tradisi permainan yang diperkenalkan bagi anak-anak Hausihu Morella. Karena itu, pengetahuan masyarakat terhadap atraksi Pukul Sapu sudah menjadi fakta sosial yang menggerakan perilaku masyarakat. Ekpsresi kebudayaan semacam ini menjadi bagian dari atraksi adat masyarakat Morella. sudah menjadi fakta sosial yang menggerakan perilaku masyarakat. Ekpsresi kebudayaan semacam ini menjadi bagian dari atraksi adat masyarakat Morella.

Sebagai atraksi adat, Upacara Ceremoni Pukul Sapu telah menjadi adat bagi masyarakat Hausihu Morella itu sendiri. Sebagai suatu atraksi adat, masyarakat Morella tidak secara otomatis memberikan sanksi bagi generasi muda yang tidak mengindahkannya. Tetapi diberikan kerelaan bagi setiap anak mudah Hausihu Morella untuk tampil mengekspresikan sifat dan sikap kepahlawanannya dalam upacara pukul Sapu tersebut. Dalam konteks itu, Adat dan hukum adat memiliki perbedaan yang tipis sekali tetapi bukan tidak bisa dibedakan. Para ahli antropologi berbeda pendapat tentang hal ini. RadcliffeBrown percaya akan adanya suatu kompleks ideide umum ialah adat yang berada di atas individu, yang sifatnya mantap dan kontinyu, dan yang mempunyai sifat memaksa. ${ }^{16}$ Dengan demikian, kalangan yang berpendirian seperti ini mengatakan bahwa tata tertib masyarakat tanpa system hukum itu tetap terjaga, karena warganya mempunyai suatu ketaatan yang seoalah-olah otomatis terhadap adat.

Untuk itu, pendapat atau teori dari kedua teoritisi ini yang berkaitan dengan adat dan hukum adat yang memberikan gambaran mengenai status atraksi Pukul sapu sebagai atraksi adat yang memiliki impilkasi hukum yang fleksibel dimana setiap orang dari warga masyarakat penggunya, memiliki sikap moralitas secara subjektif sehingga membentuk sikap dan perilaku yang menghargai upacara Pukul Sapu itu sendiri. Eksistensi Pukul sapu memberikan gambaran betapa kuatnya nilai yang terkandung dalam upacara Pukul Sapu tersebut. Upacara Ceremony Pukul Sapu ini walaupun sudah

${ }^{16}$ Koentjaraningrat. 1980. Kebudayaan, Mentalitet dan Pembangunan. Jakarta: Gramedia. h.20. 
menjadi atraksi tahunan yang sudah puluhan tahuan diadakan, tetapi masyarakat Morella terutama anak cucu dari masyarakat Morella selalu hadir lebih dulu dan berada di barisan paling depan dari pada masyarakat luar yang datang untuk menyaksikan atraksi adat Pukul Sapu tersebut. Padahal mestinya mereka mempersilahkan "orang luar" (out sider) untuk di depan Gambaran ini memberikan interpretasi kepada kita bahwa Peristiwa Pukul Sapu yang diadakan setiap tahun dan menjadi atraksi primadona masyarakat Morella sudah menjadi semacam kesadaran identitas yang berarti bahwa "atraksi adat" Pukul Sapu ini telah menjadi realitas kesadaran yang menggerakan perilaku masyarakat Morella untuk selalu hadir menyaksikannya dan bersedia berdesak-desakan dalam kerumunan ribuan penonton yang hadir.

Dalam teori antropologi, perilaku masyarakat Morella yang selalu antusias untuk lebih awal berada di arena "atraksi adat" Pukul Sapu adalah ekspresi kesadaran budaya yang secara abstrak telah menjadi kesadaran intersubjektif yang menggerakan perilaku masyarakat. Realitas ini bukan karena diatur secara sistematis untuk mendapatkan citra diri, tetapi karena perilaku tersebut telah diatur oleh struktur kesadaran yang kemudian terekspresi melalui sikap dan perilaku mereka yang di sebut sebagai pola bagi tindakan (pattern for behavior).

\section{MAKNA SIMBOLIK KAIN BERANG MERAH DAN PUKUL SAPU}

Sebagaimana sudah penulis jelaskan dalam kerangka teori mengenai Upacara Pukul Sapu ini, bahwa masalah yang dikaji dalam penelitian ini adalah kajian simbol serta pandangan hidup masyarakat Morella mengenai atraksi adat Pukul Sapu. Secara filosofis, manusia adalah animal symbolic sehingga dengan demikian, seluruh fenomena sosial adalah fenomena simbolik. Fenomena sosial yang demikian menjadi teks kebudayaan yang memerlukan penafsiran untuk menemukan makna yang terkandung di dalamnya. Untuk itu, fenomena sosial yang dikaji adalah sebuah teks budaya yang mewujud dalam fenomena simbolik. Kajian sosial budaya merupakan tafsir atas fenomena simbolik itu sendiri. Dalam konteks Simbol Upacara Pukul Sapu adalah masalah yang berkaitan dengan historisitas yang kemudian dirawat dalam struktur sosial masyarakat Morella. Untuk itu, perlu diangkat kembali penjelasan konsepsional mengenai konsep-konsep yang digunakan dalam mengkaji permasalahan ini.

Sasolisa mengatakan bahwa berbicara tentang makna dan simbol, maka keduanya tidak dapat dipisahkan satu dengan lainnya (lihat Isni Herawati, 2007). Dalam hal ini tindakan-tindakan yang sifatnya simbolik itu dimaksudkan untuk menyederhanakan sesuatu yang mempunyai makna. Sesuatu yang mempunyai makna itu adalah symbol dan maknanya adalah yang dinyatakan oleh simbol tersebut yang harus dicari lewat interpretasi atau komunikasi terhadapnya.

Pada hakekatnya, manusia adalah binatang simbolik (animal symbolicum). Melalui symbol, manusia melakukan berbagai aktivitas yang bermakna bagi dirinya dan lingkungan sekitarnya. Ekspresi manusia dalam tindakan sosialnya diperantarai oleh symbol. Dengan kata lain, apa pun yang kita gunakan adalah symbol yang memiliki makna. Misalnya, bahasa, bendera, serta alat-alat tekhnologi yang dipakai oleh manusia itu sendiri. Semua itu memberikan makna sebab eksistensi atas semua yang dimiliki oleh manusia adalah capaian kemajuan yang dinyatakan secara simbolik. Dengan demikian, simbol selalu hadir dalam ekspresi kebudayaan suatu bangsa. Simbol menjadi alat untuk 
berkomunikasi baik dengan manusia maupun dengan sesuatu yang bersifat ultimate reality. Untuk itu, symbol juga tidak dapat dipisahkan dengan religi, sebab religi merupakan suatu sistem dan simbol-simbol dimana manusia berkomunikasi dengan alam di dunia. Dengan kata lain dengan melalui upacara ritual, manusia bisa mengekpresikan gagasan-gagasan lewat tindakan-tindakan simbolik.

Konsep Pukul Sapu perlu dijelaskan untuk tidak menimbulkan kesalapahaman. Pukul Sapu sendiri merupakan simbol yang digunakan untuk mengekspresikan keberanian anak-anak muda Hausihu Morella. Konsep ini merupakan suatu penamaan terhadap prosesi upacara yang unsur utamanya adalah Sapu Lidi yang digunakan untuk memukul badan sampai berdarah. Untuk itulah upacara ini dinamakan "atrakti adat" upacara Pukul Sapu. Upacara ini dihadiri oleh orangorang yang berdesakan untuk menyaksikan bagaimana pemuda-pemuda negeri Morella saling memukul badan mereka dengan sapu lidi hingga berdarah-darah.

Konsep lain yang perlu dijelaskan adalah konsep upacara, agar tidak menyesatkan pembaca, karena dalam bahasa Inggris kita mengenal dua konsep yaitu ritual dan ceremony. Ritual itu sendiri dapat didefinisikan sebagai "Prescribed formal behavior for occasions not given over to technological routine, having reference to beliefe in mystical being or powers". ${ }^{17}$ Kepercayaan terhadap supernatural di sini sering dimanifestasikan lewat pemberian sesaji, berdoa, menyanyikan lagu-lagu sacral karena ritual ini bersifat lebih suci dan keramat. ${ }^{18}$

17 Voctor W. Turner. 1967. Symbols in ndembu ritual, in Victor Turner, The Forest of Symbols: Aspects of Ndembu Ritual. Ithaca: Crnell University Press. h. 19.

18 Irwan Abdullah. 2002. Simbol Makna dan Pandangan Hidup Jawa: Analisis Gunungan pada Upacara
Selanjutnya ceremony yang berasal dari bahasa latin (caeremonia), diartikan oleh Charles Winick dalam Dictionary of Antrhopology sebagai, "A fixed or sanctioned pattern of behavior which surrounds various phases of life, often serving religious or aesthetic ends and confirming the group's celebration of a particular situation". 19

Definisi ceremony ini menurut Abdullah ternyata sangat luas dari pada ritual karena di dalamnya meliputi sejumlah antar hubungan dan menghubungkan berbagai ritual. ${ }^{20}$ Upacara ini biasanya dihubungkan dengan peristiwa-peristiwa penting dalam masyarakat. Dengan melihat batasan ini, maka saya menggolongkan upacara Pukul Sapu sebagai upacara jenis yang kedua, yaitu ceremony karena upacara Pukul Sapu merupakan tingkah laku pengukuhan dari pernyataan kelompok terhadap situasi tertentu yang terjadi dimasa lampau, dan dihadirkan dalam setiap hari raya Idul Fitri sebagai hari kemenangan bagi umat Islam setelah sebulan menjalankan ibadah puasa yang di wajibkan oleh Allah SWT.

Konsep selanjutnya yang perlu saya jelaskan adalah konsep simbol yang merupakan konsep utama dalam kajian ini. Turner menyatakan bahwa symbol adalah: "...a thing regarded by general consent as naturally typifying or representing or recalling something by prossession of analogous qualities or by

Garebek. Yogyakarta: Balai Kajian Sejarah dan Nilai Tradisional. h. 10.

${ }_{19}$ Charles Winik. 1977. Dictionary of Antropology. New Jersey: Littlefied, Adams \& Company. h. 105.

20 Irwan Abdullah. 2002. Simbol Makna dan Pandangan Hidup Jawa: Analisis Gunungan pada Upacara Garebek. Yogyakarta: Balai Kajian Sejarah dan Nilai Tradisional. h. 10. 
association in fact or thougt." 21 Definisi ini menampakkan bahwa si pemiliknya "memadatkan" simbol-simbol kiasan atau gambaran tentang dunia nyata, baik dalam kenyataan maupun pada tingkat ide karena symbol-simbol religious merupakan petunjuk bagi perilaku manusia. Dengan kata lain, simbol dalam masyarakat Morella sebagai bagian dari masyarakat Maluku tidak lain merupakan petunjuk bagi perilaku orang Morella. Dengan demikian symbol merupakan alat bantu yang dapat menggerakan masyarakatnya. ${ }^{22}$

Pendekatan yang mau digunakan untuk menganalisis masalah simbol dalam upacara Pukul Sapu ini adalah pendekatan yang disebut Turner sebagai "prosesual simbologi”, yaitu suatu kajian mengenai bagaimana symbol menggerakan tindakan sosial dan melalui proses yang bagaimana symbol memperoleh dan memberikan arti kepada masyarakat dan pribadi. ${ }^{23}$ Pendekatan ini akan memungkinkan kita untuk mengungkapkan arti-arti symbol dan selanjutnya mengetahui pikiran-pikiran atau ide-ide masyarakat, apalagi mengingat bahwa symbol merupakan pedoman bagi kelompok-kelompok, hubungan-hubungan, norma-norma, dan kepercayaan masyarakat.

Dalam memaknai sebuah atraksi budaya yang dikaitkan dengan seperangkat simbol yang digunakan oleh masyarakat pengguna maka, jalan yang harus dilakukan adalah melakukan analisis deept interpretation (interpretasi mendalam) yang

21 Voctor W. Turner. 1967. Symbols in ndembu ritual, in Victor Turner, The Forest of Symbols: Aspects of Ndembu Ritual. Ithaca: Crnell University Press. h. 19.

22 Irwan Abdullah. 2002. Simbol Makna dan Pandangan Hidup Jawa: Analisis Gunungan pada Upacara Garebek. Yogyakarta: Balai Kajian Sejarah dan Nilai Tradisional. h. 12.

${ }^{23}$ William Armand Lessa and Evon Z. Vogt (eds). 1979. Reader in Comparative Religion: an Anthropological Approach. New York: Harper \& Row Publishers. h. 91. tentu saja bukan berdasarkan subjektifitas peneliti. Peneliti hanyalah seorang "outsider" orang luar yang tidak tahu apa-apa tentang objek yang diteliti. Untuk itu, agar mendapatkan interpretasi yang mendalam, maka peneliti harus melihat makna yang dikemukakan oleh insider dalam memaknai realitas yang dikonstruksi. Dari situ barulah dapat dilakukan interpretasi mendalam berdasarkan worldview atau paradigma yang dimiliki.

Dalam perdebatan mengenai teori-teori yang menjadi acuan dalam menjelaskan realitas sosial yang diamati, para teortisi berbeda pendapat atau berbeda perspektif. Dalam konteks itu, saya ingin menampilkan bagaimana Boas, salah seorang ahli antropologi yang mengkriti cara menjelaskan realitas budaya suatu bangsa berdasarkan cara-cara deduktif sebagaimana kaum evolusionis. Boas berpendapat bahwa sebuah teori tidak lain berfungsi untuk melakukan deduksi sehingga imajinasi yang hanya mendasarkan pada dugaan saja dapat dikendalikan (lihat Poerwanto, 2010). Dikatakannya, bahwa suatu deduksi seperti yang dilakukan kaum evolusionis, hanya tepat dilakukan oleh para ahli filsafat yang hanya duduk di balik menja saja (arm chair philosophers). Untuk itu, dalam menjelaskan realitas, kita harus mendalami secara apa adanya realitas yang diteliti.

Upacara Pukul Sapu memiliki makna yang mendalam bagi masyarakat penggunanya. Masyarakat menganggap atraksi adat Pukul Sapu sudah menjadi sebuah atraksi yang dilakukan oleh masyarakat Hausihu Morella sejak masih di negeri Lama Kapahaha. Sejak dulu, sebagai suatu komunitas yang hidup dalam suatu dusun-dusun kecil, masyarakat Hausihu Morella mempraktekan ekspresi keberaniannya dengan saling memukul badan dengan Sapu Lidi yang 
bahannya dari pohon enau. Sapu Lidi digunakan sebagai symbol yang menggantikan pedang yang digunakan untuk memotong lawan. Sejak dulu, masyarakat yang masih dalam keadaan sederhana, pedang atau alat yang digunakan sebagai senjata untuk melindungi diri adalah parang. Walaupun secara spesifik, parang menjadi senjata utama untuk di bawa kemanamana, ada juga peralatan lain seperti tombak dan panah yang disimpan di rumah.

Untuk itu, dalam mempraktekan simbol keberanian itu, masyarakat Hausihu Morella menggunakan Sapu Lidi sebagai simbol keberanian. Bagaimana anak-anak Hausihu Morella belajar seni berperang dengan menggunakan Sapu Lidi sebagai alat yang mewakili kesadaran atas keberanian yang dimiliki oleh generasi muda masyarakat Hausihu Morella. Sapu Lidi mewakili simbol pedang atau "parang" dalam istilah Maluku. Sapu Lidi digunakan sebab alat ini mudah untuk dikumpulkan dalam jumlah yang banyak. Dibandingkan dengan alat-alat yang lain, misalnya kayu atau sejenisnya, belum bisa mewakili Sapu Lidi yang bisa diambil dalam jumlah yang banyak dan mudah untuk dibawabawa. Sapu Lidi juga bisa diambil dari daun pohon kelapa. Tetapi Sapu Lidi dari pohon kelapa tidak digunakan sebab bahannya terlalu ringan dan kurang menantang nyali keberanian dalam atraksi adat Pukul Sapu tersebut. Praktek seperti ini dalam catatan etnografi tentang berbagai suku bangsa di dunia, dimana terjadi situasi saling menaklukan antara kekuatan satu suku bangsa kepada suku bangsa yang lain, terdapat atrkasi anak-anak muda mempraktekan seni berperang dengan menggunakan kayu seperti yang diparketkan oleh anak-anak kazastan untuk melawan tentara Mongol.

Dalam konteks Upacara Pukul Sapu, masyarakat Hausihu Morella memiliki keberanian yang kuat dan besar yang terobjektivasi secara terstruktur dalam budaya masyarakat. Untuk itu, symbol Pukul Sapu Lidi ke badan hingga berdarah-darah merupakan ekspresi keberanian yang kuat sekali yang telah tertanam dalam memori masyarakat Morella sehingga mampu menggerakan perilaku. Sebagaimana dijelaskan oleh Turner bahwa symbol mampu menggerakan tindakan sosial dan melalui proses yang dimiliki secara spesifik dari masyarakat tersebut untuk memperoleh dan memberikan arti kepada masyarakat dan individu.

Proses semacam itu oleh Turner disebut sebagai "Prosesual Simbologi" yaitu suatu kajian mengenai bagaimana symbol menggerakan tindakan sosial dan melalui proses yang bagaimana symbol memperoleh dan memberikan arti kepada masyarakat dan pribadi. ${ }^{24}$ Pendekatan ini akan memungkinkan kita untuk mengungkapkan arti-arti symbol dan selanjutnya mengetahui pikiran-pikiran atau ide-ide masyarakat, apalagi mengingat bahwa symbol merupakan pedoman bagi kelompok-kelompok, hubungan-hubungan, norma-norma, dan kepercayaan masyarakat.

Kesadaran masyarakat Hausihu Morella terhadap makna atraksi adat "Pukul Sapu" sebagaimana tergambar dalam penjelasan di atas memperlihatakan kontinuitas semangat anak cucu Kapitan Tulukabeesy dalam melawan penjajah Belanda. Atraksi adat Puku Sapu dengan mengikuti acara yang penulis sebut sebagai malam budaya yang memperagakan sebuah tater yang merefleksikan semangat perjuangan kapitan Tulukabessy dalam melawan penjajah Belanda. Acara malam budaya tersebut juga di isi dengan

${ }^{24}$ William Armand Lessa and Evon Z. Vogt (eds). 1979. Reader in Comparative Religion: an Anthropological Approach. New York: Harper \& Row Publishers. h. 91. 
membacakan puisi-puisi atau menyanyikan syairsyair Lani atau lebih umum disebut kapata.

Acara atraksi Pukul Sapu memberikan dua kategori dalam menjelaskan makna atraksi adat "Pukul Sapu". Pertama, Atraksi adat "Pukul Sapu" merupakan refleksi atas semangat perjuangan kapitan dan para Malessi yang dengan gigih berjuang melawan penjajah Belanda. Eksistensi Budaya Pukul Sapu ini merupakan bukti bahwa masyarakat Hausihu Morella sangat menjungjung tinggi nilai-nilai heroik para leluhur dalam melawan penjajah Belanda. Dalam konteks penjajahan ini perlu diberikan catatan kaki sebagai refleksi dari suatu nilai yang penting bagi masyarakat Hausihu Morella yakni penjajahan bukan hanya sebagai sesuatu yang bersifat fisik saja, tetapi juga bersifat mental dimana melawan penjajah merupakan bentuk kemerdekaan diri dari belnggu harga diri. Untuk itu, penjajahan di atas dunia adalah musuh kemanusian yang menjadi agenda kemanusian semua negara-negara di dunia. Eksistensi Pukul Sapu merupakan simbol semangat kepahlawanan yang diinternalisasikan oleh seluruh anak-anak negeri Haussihu Morella melalui keikutsertaan mereka dalam perayaan atraksi adat Pukul Sapu ini. Perayaan ini merupakan upacara seremonial yang diadakan sebagai bentuk komitmen mereka dalam memenuhi janji para leluhur yang kalah dalam perang kapahaha. Kapitan dan para Malessy mengikrarkan satu janji agar kekalahan ini harus diperingati oleh anak cucu negeri Hausihu Morella atas kekalahan melawan penjajah Belanda.

Kedua, Memukul badan hingga berdarahdarah merupakan symbol yang bermakna semangat tanpa pernah surut. Kekalahan di sadari sebagai awal bagi perdamaian yang tercipta. Sebab kekalahan perang Kapahaha terjadi ketika kapitan Tulukabessy tertangkap oleh Belanda.
Perang kapahaha sendiri merupakan perang yang sangat besar, sebab perang ini dibantu oleh berbagai malessy dari berbagai daerah yang ada di Maluku maupun dari luar Maluku yaitu dari kerajaan Goa dan Tuban. Kekalahan sebagai awal perdamaian, sebab setelah perang kapahaha ini masyarakat Hausihu Morella tidak lagi dijajah oleh Belanda. Bahkan peperangan pun sudah tidak terjadi lagi. Untuk itu, semangat perjuangan ini kemudian disimbolkan dengan atraksi adat Pukul Sapu sebagai bagian dari kebrelangsungan perjuangan para kapitan dalam proses hidup masyarakat Hausihu Morella. Proses semacam ini juga akan menjadi suatu identitas budaya di tengah budaya-budaya masyarakat lainnya. Dalam kajian postkolonial sebagaimana dijelaskan oleh Faidah (2008), atrkasi adat Pukul Sapu ini memposisikan masyarakat Hausihu Morella sebagai pihak subaltern atau pihak yang tertindas. Masyarakat Hausihu Morella kemudian memperkenalkan suatu atraksi yang meneguhkan semangat perlawanan terhadap penjajah Belanda dengan atraksi adat Pukul Sapu ini yang kemudian tersosisialisasi hingga saat ini.

Atraksi adat Pukul Sapu memiliki nilai historisitas yang tinggi bagi masyarakat Hausihu Morella. Untuk itu, eksistensi atraksi adat "Pukul Sapu" menjadi tanda akan perawatan nilai-nilai perjuangan yang dilakukan oleh anak cucu negeri Hausihu Morella.

\section{PENUTUP}

Atraksi adat Pukul Sapu Lidi memiliki makna yang menggerakan perilaku masyarakat Hausihu Morella. Simbol-simbol yang digunakan memiliki makna yang terkandung di dalamnya. Simbol dan makna yang digali dari masyarakat tersebut memberikan kemudahan dalam melakukan interpretasi. Proses interpretasi tersebut dikaitkan dengan pandangan yang 
dimiliki oleh masyarakat setempat. Dalam menganalisis kajian yang dikemukakan dalam penelitian ini, saya menggali secara mendalam proses historisitas yang menjadi pintu masuk dalam memahami makna yang tersembunyi di dalam simbil-simbol yang di gunakan.

Dalam proses sejarah tersebut, memberikan cara pandang yang menjadi kesadaran kolektif masyarakat. Untuk sampai pada kesimpulan mengenai masalah yang diajukan dalam penelitian ini, saya ingin menjelaskan bagaimana sejarah dipahami. Sejarah sebagaimana kita ketahui, memiliki dua aspek yang terdapat di dalamnya. Pertama, sejarah pragmatis, yakni sejarah yang merupakan peristiwa masa lampau yang diingat secara runut peristiwa-persitiwanya. Kesadaran sejarah semacam ini kita sebuat sebagai kesadaran sejarah pragmatis. Kedua, sejarah filosofis, yakni sejarah sebagaimana diingat dalam runutan peristiwanya itu, dimakna sebagai spririt perubahan bagi masyarakat itu sendiri. Kesadaran sejarah filosofis inilah yang menjadi penting untuk didayagunakan. Sebab proses transformasi kesadaran sejarah semacam ini memberikan apresiasi bagi makna yang terkandung di dalamnya. Peristiwa sejarah tidak dianggap sebagai kumpulan benda mati yang tanpa makna apapu. Seluruh proses sejarah dianggap memiliki spirit bagi upaya transformasi perubahan suatu masyarakat.

Untuk itu, peristiwa atraksi adat Pukul sapu Lidi ke badan hingga berdarah-darah di Sawatelu pada tahun 1946 itu memiliki makna tertentu yang perlu diungkapkan. Dalam proses penelitian ini ada tiga pertanyaan penelitian yang dikemukakan. Pertanyaan mengenai multi makna dalam symbol yang digunakan (multivocal) sebagai dijelaskan dalam rujukan teori, dalam penelitian ini ditemukan bahawa symbol pukul sapu memiliki makna yang tidak tunggal. Pertama Pukul Badan hingga berdarah-darah selain memiliki makna keberanian dalam memperjuangkan kemerdekaan dan kebebasan, juga memiliki makna konsistensi dalam setiap perjuangan. Makna konsistensi ini dapat dilihat dalam jargon "Lawa Mena Haulala". Maju terus pantang mundur. Untuk itu, makna yang terkandung dalam atraksi adat Pukul Sapu Lidi ini memiliki lebih dari satu makna.

Dalam konteks penggunaan Sapu Lidi sebagai symbol ekspresi keberanian dan konsistensi, Sapu Lidi adalah simbol pengganti pedang. Selain bermakna kelenturan dalam bernegosiasi, juga bermakna sebagai konsistensi menegakan kebenaran seperti tersimbolkan dalam hurup Alif yang berdiri tegak. Jadi, Sapu Lidi adalahsimbol huruf alif dalam urutan pertama hijaiyyah (ururtan hurup arab). Makna semacam ini memang tidak diketahui oleh hampir sebagaian besar masyarakat Hausihu Morella. Hanya sebagaian kecil masyarakat saja yang memberikan pemaknaan dalam melihat symbolsimbol yang dipergunakan dalam atraksi adat Pukul Sapu tersebut.

Pesta Adat Pukul sapu ini adalah atraksi yang menjadi tontonan budaya yang menarik. Pesta Budaya ini menjadi identitas budaya yang memberikan keunikan budaya local serta menambah hasanah kebudayaan nasional. Pesta Budaya Pukul Sapu Lidi menjadi identitas yang terus dilakukan setiap tahun. Hal ini merupakan bagian dari upaya menarasikan, serta mendokumnetasikan jati diri masyarakat Hausihu Morella itu sendiri. Tentu saja, persoalan ini tidak hanya menjadi sesuatu yang berjalan mulus, tetapi juga bisa mendatangkan konflik. Konflik identitas serta perebutan hak legitimasi atas Pesta Adat Pukul Sapu Lidi ini perlu dilihat sebagai bagian dari kajian tersendiri. 


\section{DAFTAR PUSATAKA}

Abdullah, Irwan. 2006. Konstruksi dan Reproduksi Kebudayaan. Yogyakarta: Pustaka Pelajar 2002. Simbol Makna dan Pandangan Hidup Jawa: Analisis Gunungan pada Upacara Garebek. Yogyakarta: Balai Kajian Sejarah dan Nilai Tradisional

Abdullah, Irwan., et.all. 2008. Agama dan Kearifan Lokal dalam Tantangan Global. Yogyakarta. Pustaka Pelajar

Baal, J. Van. 1971. Symbols for Communication: an Introduction to the Anthropological Study of religion ( Sudies of Developing Countries 11). Asen: Van Gorrcum

Daeng, J., Hans. 2008. Manusia, Kebudayaan dan Lingkungan: Suatu Tunjauan Antropologi. Yogyakarta: Pusataka Pelajar Geertz, Clifford. 1973. The Interpretation of Culture. New York: Basic Books.

Giddens, Anthony. 1989. Sosiology. Cambridge: Polity Press

Kuntowijoyo. 2006. Budaya dan Masyarakat. Yogyakarta: Tiara Wacana

Lessa, William Armand and Evon Z. Vogt (eds). 1979. Reader in Comparative Religion: an Anthropological Approach. New York: Harper \& Row Publishers.

Sinaga, Lukito Martin. 2004. Identitas Poskolonial "Gereja Suku” dalam Masyarakat Sipil. Yogyakarta. LkiS

Turner, Voctor W. 1967. Symbols in ndembu ritual, in Victor Turner, The Forest of Symbols: Aspects of Ndembu Ritual. Ithaca: Crnell University Press.
Winik, Charles. 1977. Dictionary of Antropology. New Jersey: Littlefied, Adams \& Company.

Koentjaraningrat. 1980. Kebudayaan, Mentalitet dan Pembangunan. Jakarta: Gramedia

Imam Habibudin. 2006. "Kearifan Lokal Masyarakat”, dalam Pengelolaan Repong Damar Untuk Mendukung Konservasi Lingkungan di Pesisir Krui Lampung Barat. (Tesis) Pasca Sarjana.Yogyakarta: UGM,.

Sumintarsih. 2005. Kearifan Lokal Nelayan Madura. Yogyakarta: BKSNT. 